\title{
Reactivity vs stability of cyclopropenium substituted phosphonium salts
}

\author{
Rachid Taakili, ${ }^{[a]}$ Carine Duhayon, ${ }^{[a]}$ Noël Lugan, ${ }^{[a]}$ Yves Canac*[a]
}

Rachid Taakili, Dr. Carine Duhayon, Dr. Noël Lugan, Dr. Yves Canac

[a] LCC-CNRS, Université de Toulouse, CNRS

205 route de Narbonne, 31077 Toulouse Cedex 4 (France)

E-mail: yves.canac@1cc-toulouse.fr

https://www.lcc-toulouse.fr/article388.html

\begin{abstract}
The stability $v s$ reactivity of electrophilic 3-(triphenylphosphonio)-cyclopropenium salts towards a neutral nucleophile, such as triphenylphosphine, is reported. Depending on the nature of cyclopropenyl substituents $(R)$, the three-membered cyclic structure is preserved $(R=P h)$ or evolves by ring opening to the isomeric linear allene $(\mathrm{R}=\mathrm{Mes})$. The respective formation of 1,3bis(triphenylphosphonio)-2,3-diphenylcyclopropene and 3,3-bis(triphenylphosphonio)-1,1dimesitylallene products is rationalized on the basis of steric and electrostatic constraints.
\end{abstract}

Keywords: Allene, charge, cyclopropene, cyclopropenium, phosphonium, ring strain. 


\section{Introduction}

Three-membered cycles are of considerable interest because of their essential role as intermediates in many chemical transformations. ${ }^{[1]}$ Their inherent ring strain causes a high reactivity that could lead to ring-opening ${ }^{[2]}$ or ring-expansion reactions. ${ }^{[3]}$ Among three-membered cycles, cyclopropenium cations belong to a category apart due to the delocalization of two $\pi$-electrons over three $3 p$ orbitals which confers higher stability. ${ }^{[4]}$ Beyond aromatic effects, the nature of cyclopropenyl substituents play a determinant role in the stability $v s$ reactivity of these two $\pi$-electron Hückel prototypes. ${ }^{[5]}$ In comparison with cyclopropeniums bearing only carbon substituents, amino groups due to their strong $\pi$-donating effect and the electronegativity of nitrogen induce additional stability which has the consequence of placing aminocyclopropeniums among the most stable carbocations. ${ }^{[6]}$ Amino substituents are not only responsible for the characterization of a wide range of cyclopropeniums of type $\mathbf{A}$, but they also allowed to stabilize cyclopropenylidenes $\mathbf{B}$, the ensuing carbenic species. ${ }^{[7]}$ Among cyclopropenylidene-phosphorus derivatives, stabilized phosphenium cations of type $\mathbf{C}$ were recently prepared for the purpose of accessing novel $\alpha$-cationic phosphine ligands ${ }^{[8]}$ Cyclopropenium substituted phosphonium salts of type $\mathbf{D}$ were briefly investigated with the main objective of designing highly electrophilic phosphorus cations that can serve as Lewis acid initiators. ${ }^{[9]}$ Thanks to the critical effect of $\pi$-donating amino substituents, a large gamme of unsaturated three membered cycles A-D, neutral, mono- or dicationic in nature, were thus isolated (Figure 1).
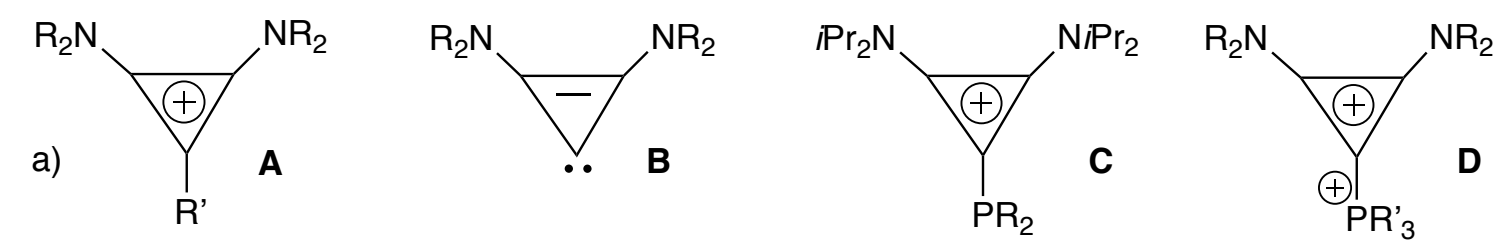

$$
\begin{aligned}
& \mathrm{R}=\mathrm{Alk}, \mathrm{Ar} \\
& \mathrm{R}^{\prime}=\mathrm{H}, \mathrm{Alk}, \mathrm{Ar}, \mathrm{Hal}, \mathrm{NR}_{2}, \mathrm{OR}, \ldots
\end{aligned}
$$

$$
\mathrm{R}=\mathrm{Alk}, \mathrm{Ar}
$$

$\mathrm{R}=$ Alk $\mathrm{R}^{\prime}=\mathrm{Alk}, \mathrm{Ar}, \mathrm{NR}_{2}$

b)

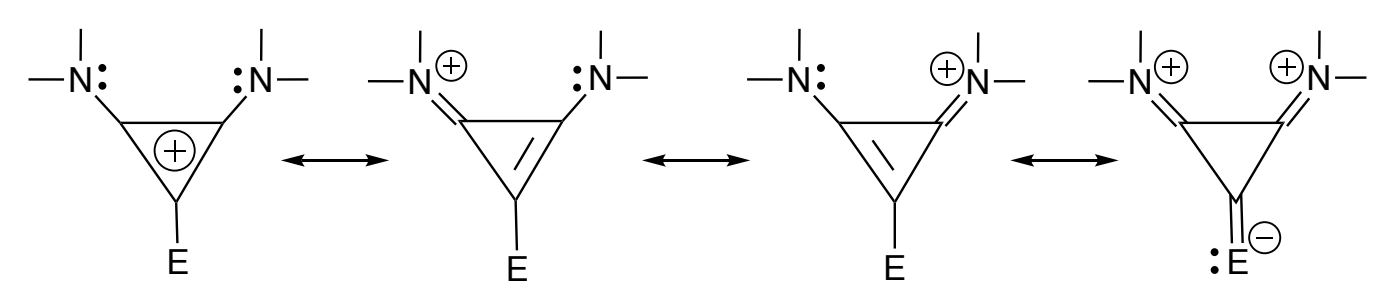

Figure 1. a) Representation of known cyclopropenium type-systems A-D based on $\pi$-donating amino substituents. b) Cyanine-type resonance structures of cyclopropenium type-systems $\mathbf{A}-\mathbf{D}$. 
Based on this long history of cyclopropenium cations, the present article aims to evaluate the role of the substitution pattern in the stability $v s$ reactivity of cyclopropenium substituted phosphonium salts of type $\mathbf{D}$, the dicationic representatives of this fascinating family of two $\pi$-electron aromatic systems that have been poorly studied to date and may be of fundamental and applied interest.

\section{Results and Discussion}

According to the recent report of Alcarazo and co-workers, 3-triphenylphosphonio-1,2bis(diisopropylamino)cyclopropenium $[2](\mathrm{OTf})_{2}$ was smoothly prepared in good yield from related 3chlorocyclopropenium salt $[1](\mathrm{OTf})$ and $\mathrm{PPh}_{3}$ in the presence of $\mathrm{NaOTf}$ in THF at $60{ }^{\circ} \mathrm{C}$ (Scheme 1 , method a). ${ }^{[9]}$ The dicationic phosphonium $[2](\mathrm{OTf})_{2}$ was also readily obtained by reacting cyclopropenium precursor [1](OTf) with the $\mathrm{PPh}_{3} / \mathrm{Me}_{3} \mathrm{SiOTf}$ system in $\mathrm{CH}_{2} \mathrm{Cl}_{2}$ at room temperature (Scheme 1, method b). ${ }^{[10]}$

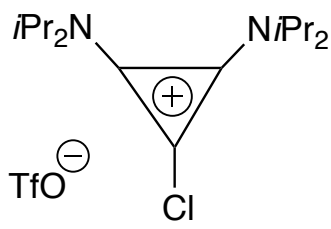

[1](OTf)

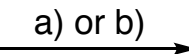

$2 \mathrm{TfO}^{\ominus}$ $\oplus_{\mathrm{PPh}_{3}}$

$[2](\mathrm{OTf})_{2}$

Scheme 1. Preparation of 3-triphenylphosphonio-1,2-bis(diisopropylamino)cyclopropenium [2](OTf) 2 from 3-chlorocyclopropenium [1](OTf). a) (1.5 eq.) $\mathrm{PPh}_{3}$, (1.1 eq.) $\mathrm{NaOTf}$, THF, $60{ }^{\circ} \mathrm{C}, 95 \%$; b) (1.1 eq.) $\mathrm{PPh}_{3}$, (1.1 eq.) $\mathrm{Me}_{3} \mathrm{SiOTf}, \mathrm{CH}_{2} \mathrm{Cl}_{2}, \mathrm{RT}, 90 \%$.

As observed for the tetrafluoroborate analogue, ${ }^{[9]}$ the ${ }^{31} \mathrm{P}$ NMR spectrum of [2](OTf $)_{2}$ displayed a single signal shifted downfield relative to $\mathrm{PPh}_{3}\left(\delta_{\mathrm{P}}-5.9 \mathrm{ppm}\right)$ at $\delta_{\mathrm{P}} 9.3 \mathrm{ppm}$. In the ${ }^{13} \mathrm{C}$ NMR spectrum, the $\mathrm{C}-{ }^{-} \mathrm{PPh}_{3}$ carbon atom was found to be slightly deshielded ( $\delta_{\mathrm{C}} 140.9 \mathrm{ppm}$, brs) with respect to the $\mathrm{C}-\mathrm{Cl}$ carbon atom of precursor $[1](\mathrm{OTf})\left(\delta_{\mathrm{C}} 133.4 \mathrm{ppm}, \mathrm{s}\right)$ in agreement with a $s p^{2}$-type carbon atom. ${ }^{[11]}$ The exact structure of $[2](\mathrm{OTf})_{2}$ was established by X-ray diffraction analysis of single crystals obtained from a $\mathrm{CH}_{2} \mathrm{Cl}_{2} / \mathrm{Et}_{2} \mathrm{O}$ mixture at room temperature (Figure 2). ${ }^{[12]}$ In the solid state, the ring and the amino substituents are nearly coplanar confirming the interaction of the nitrogen lone pairs with the $\pi$-system of the ring. It is also worth noting the quasi-tetrahedral environment of 
the phosphorus atom and the absence of interaction of the two $\mathrm{TfO}^{-}$counteranions with the cyclopropenium bearing the phosphonium moiety.

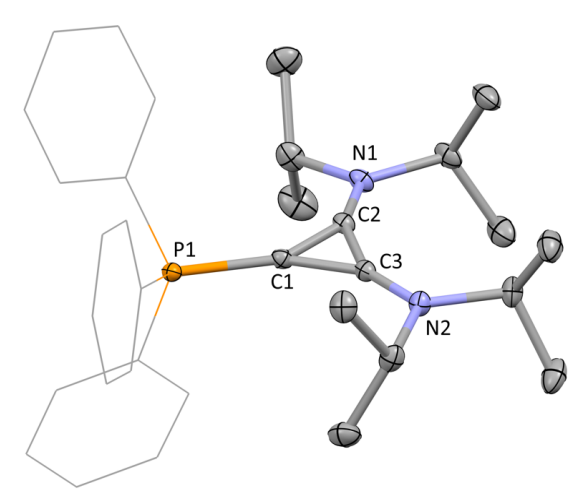

Figure 2. Perspective view of the cationic part of cyclopropenium substituted phosphonium salt $[2](\mathrm{OTf})_{2}$ with thermal ellipsoids drawn at the $30 \%$ probability level (for clarity, the $\mathrm{H}$ atoms are omitted). Selected bond distances $(\AA)$ and angles $\left({ }^{\circ}\right)$ : C1-P1 1.7776(19), C1-C2 1.384(2), C2-C3 1.424(3), C1-C3 1.389(3), C2-N1 1.299(2), C3-N2 1.291(2), P1-C1-C2 143.93(15), P1-C1-C3 154.26(15), C2-C1-C3 61.80(13), C1-C2-N1 146.91(19).

Anticipating an exaltation of the electrophilic character for cyclopropenium [2](OTf $)_{2}$ due to its dicationic character, the addition of a second equivalent of $\mathrm{PPh}_{3}$ was considered. However, whatever the conditions of the reaction (solvent, temperature, number of equivalents), ${ }^{31} \mathrm{P}$ NMR spectroscopy evidenced only the resonance of $[2](\mathrm{OTf})_{2}$ along with free $\mathrm{PPh}_{3}$. The inertness of cyclopropenium $[2](\mathrm{OTf})_{2}$ towards a soft nucleophile such as $\mathrm{PPh}_{3}$ was reasonably attributed to the dominating contribution of cyanine-type resonance forms in the description of $[2](\mathrm{OTf})_{2}$ due to the strong interaction of the $\pi$-donor nitrogen groups with the aromatic system (Figure $1 \mathrm{~b}$ ).

To overcome the overly stabilizing effect of $\mathrm{NiPr}_{2}$ substituents on the cyclic structure, 1,2diarylcyclopropenes were then selected as alternative precursors. ${ }^{[13]}$ Treatment of 3,3-dichloro-1,2diphenylcyclopropene 3 with a stoechiometric amount of $\mathrm{PPh}_{3}$ in $\mathrm{CH}_{2} \mathrm{Cl}_{2}$ at room temperature afforded the corresponding 3-triphenylphosphoniocyclopropene [5] Cl in 90\% yield (Scheme 2). The ${ }^{31} \mathrm{P}$ NMR spectrum of [5] Cl displayed a singlet at $\delta_{\mathrm{P}} 29.1 \mathrm{ppm}$ shifted downfield relative to [2](OTf $)_{2}$ ( $\delta \mathrm{P} 9.3 \mathrm{ppm}$ ), in the typical range for phosphonium derivatives. ${ }^{[14]}$ The cyclopropenic structure was indicated by the presence of the upfield ${ }^{13} \mathrm{C}$ NMR resonance of the cyclic $s p^{3}$-type carbon atom with 
proper multiplicity $\left(\delta_{\mathrm{C}} 47.2 \mathrm{ppm},\left(\mathrm{d},{ }^{1} J_{\mathrm{CP}}=111.7 \mathrm{~Hz}\right)\right.$ ). The cationic nature of $[5] \mathrm{Cl}$ was unambiguously confirmed by ESI mass spectroscopy $\left(5^{+}: \mathrm{m} / \mathrm{z} 487.1\right)$.

The same reactivity was observed from related 3,3-dichloro-1,2-dimesitylcyclopropene 4 as illustrated with the quantitative formation of 3-triphenylphosphoniocyclopropene [6]Cl under the same conditions. As observed for $[5] \mathrm{Cl},{ }^{31} \mathrm{P}$ and ${ }^{13} \mathrm{C}$ NMR spectra of $[6] \mathrm{Cl}$ confirmed its cationic character as well as the direct linkage of the phosphonium moiety to the cyclopropene ring $\left(\delta_{\mathrm{P}} 30.4\right.$ $\operatorname{ppm}(\mathrm{s}) ; \delta_{\mathrm{C}} 52.4 \mathrm{ppm},\left(\mathrm{d},{ }^{1} J_{\mathrm{CP}}=109.7 \mathrm{~Hz}\right)$ ) (Scheme 2). It should be noted that if spectroscopic data of $[5-6] \mathrm{Cl}$ are here in favor of a cyclopropenic structure, 3-halogenocyclopropenes are known to be more or less displaced to their cyclopropenium form depending on the ability of the halide ion to dissociate from the cation. ${ }^{[15]}$

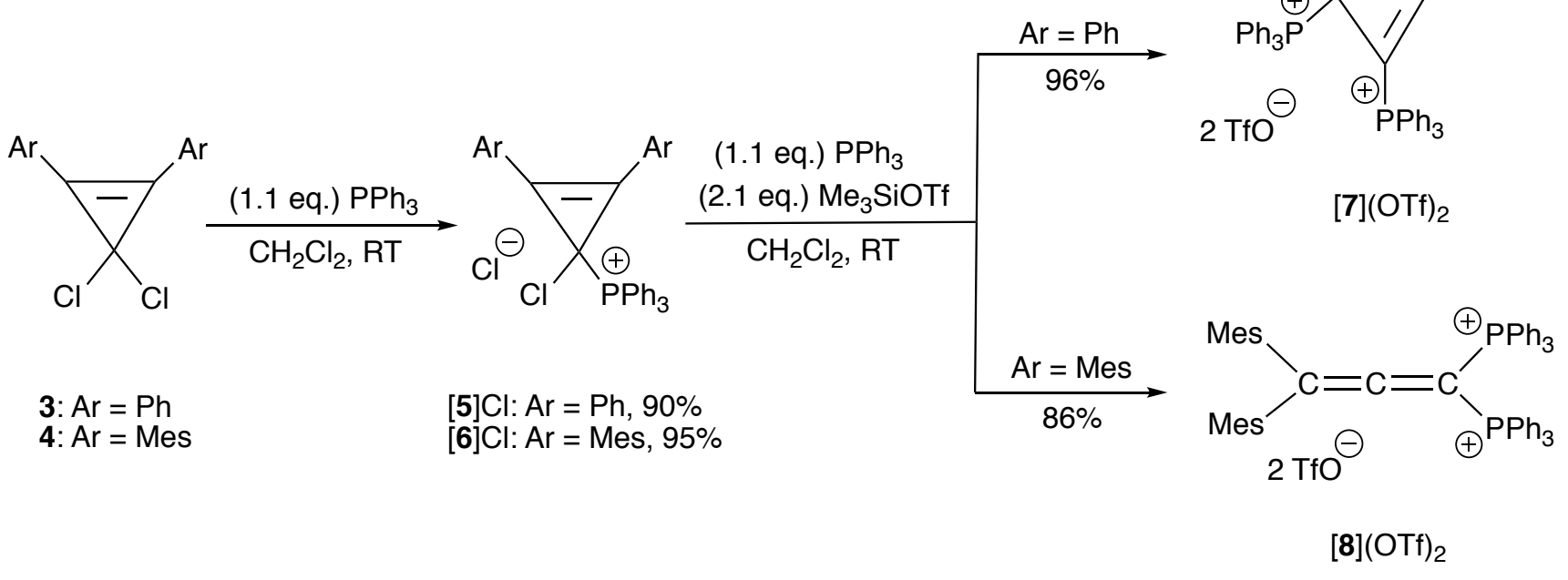

Scheme 2. Preparation of bis(phosphonium) salts [7-8](OTf) from corresponding 3,3-dichloro-1,2diarylcyclopropene precursors 3-4 via 3-phosphoniocyclopropenes [5-6]Cl.

To further evaluate the role of cyclopropenyl substituents, 3-phosphoniocyclopropene [5]Cl was treated with a stoechiometric amount of $\mathrm{PPh}_{3}$ in the presence of two equivalents of $\mathrm{Me}_{3} \mathrm{SiOTf}_{\text {in }}$ $\mathrm{CH}_{2} \mathrm{Cl}_{2}$ at room temperature. ${ }^{31} \mathrm{P} \mathrm{NMR}$ monitoring revealed the disappearance of the signal of [5]Cl with concomitant appearance of a AX-type system $\left(\delta_{\mathrm{P}} 15.0 \mathrm{ppm}(\mathrm{d}), 30.3 \mathrm{ppm}(\mathrm{d}), J_{\mathrm{PP}}=10.5 \mathrm{~Hz}\right)$ giving a first indication about the nature and the environment of the two phosphorus atoms. In the latter, isolated with a yield of $96 \%$ and expected to contain two phosphonio moieties, the preservation of the cyclopropene ring was evidenced by the presence of the characteristic carbon atom of $s p^{3}$-type in the high field region $\left(\delta_{\mathrm{C}} 39.3 \mathrm{ppm},\left(\mathrm{d},{ }^{1} J_{\mathrm{CP}}=74.4 \mathrm{~Hz}\right)\right.$ ) of the ${ }^{13} \mathrm{C}$ NMR spectrum (Scheme 2$)$. The 
dicationic character was confirmed from ESI mass spectrocopy $\left(\mathrm{m} / z\right.$ 863.2 $\left.[\mathrm{M}-\mathrm{TfO}]^{+}\right)$. X-ray diffraction analysis of colorless crystals, deposited from $\mathrm{CH}_{2} \mathrm{Cl}_{2} / \mathrm{Et}_{2} \mathrm{O}$ at $-20{ }^{\circ} \mathrm{C}$, allowed finally this dicationic salt to be assigned to the cyclopropene [7](OTf $)_{2}$ bearing two triphenylphosphonio groups (Figure 3, left). ${ }^{[12]}$ Compound [7](OTf $)_{2}$ corresponds in fact to a chiral cyclopropene in which the two cationic fragments are connected to two carbon atoms of different nature, of $s p^{2}$ - and $s p^{3}$-type, respectively. The unsaturated three-membered cycle is clearly indicated by the presence of two single $\mathrm{C}-\mathrm{C}$ bonds $(\mathrm{C} 1-\mathrm{C} 2: 1.525(4) ; \mathrm{C} 1-\mathrm{C} 3: 1.540(4) \AA)$ and one double $\mathrm{C}=\mathrm{C}$ bond $(\mathrm{C} 2-\mathrm{C} 3: 1.307(4) \AA)$. Noteworthy, the related $\mathrm{C} 2$ and $\mathrm{C} 3$ carbon atoms reside in a planar environment while the $\mathrm{C} 1$ carbon atom is characterized by a distorted tetrahedral geometry.

A similar reactivity was then expected from related 3-phosphoniocyclopropene [6]Cl. Addition of an equivalent of $\mathrm{PPh}_{3}$ in the presence of $\mathrm{Me}_{3} \mathrm{SiOTf}$ in $\mathrm{CH}_{2} \mathrm{Cl}_{2}$ at room temperature to [6]Cl resulted in the formation of bis(phosphonium) salt $[8](\mathrm{OTf})_{2}$ in $86 \%$ isolated yield (Scheme 2). However, surprisingly, the ${ }^{31} \mathrm{P}$ NMR spectrum exhibited only the appearance of a single resonnance $\left(\delta_{\mathrm{P}} 25.3\right.$ ppm), thus precluding the formation of a disymmetrical cyclopropene similar to that observed in the previous case. Mass spectroscopy $\left(\mathbf{8}^{+}: \mathrm{m} / \mathrm{z} 947.3[\mathrm{M}-\mathrm{TfO}]^{+}\right)$accounted for the presence of two triphenylphosphonio moieties in agreement with the expected dicationic nature. The fascinating structure of $[8](\mathrm{OTf})_{2}$ was further assigned on the basis of its ${ }^{13} \mathrm{C}$ NMR chemical shifts, in particular by the presence of three triplets attributed to quaternary carbon atoms with one of them appearing at very low field $\left(\delta_{\mathrm{C}} 227.6 \mathrm{ppm}\left(\mathrm{t}, J_{\mathrm{CP}}=3.0 \mathrm{~Hz}\right) ; \delta_{\mathrm{C}} 117.7 \mathrm{ppm}\left(\mathrm{t}, J_{\mathrm{CP}}=13.2 \mathrm{~Hz}\right) ; \delta_{\mathrm{C}} 75.7 \mathrm{ppm}\left(\mathrm{t}, J_{\mathrm{CP}}=\right.\right.$ 74.2 Hz)). The allenic structure deduced from the ${ }^{13} \mathrm{C}$ NMR spectrum was finally confirmed by X-ray diffraction analysis of colorless crystals obtained from a $\mathrm{CH}_{2} \mathrm{Cl}_{2} / \mathrm{Et}_{2} \mathrm{O}$ mixture at room temperature (Figure 3, right). ${ }^{[12]}$ The solid state analysis confirms that the central carbon atom is in a quasi linear environment $\left(\mathrm{C} 1-\mathrm{C} 2-\mathrm{C} 3179.991^{\circ}\right)$, as would be anticipated for such unsaturated derivative with the two allenic $\mathrm{C}=\mathrm{C}$ bonds not significantly different $(\mathrm{C} 1-\mathrm{C} 2$ : $1.325(4) \AA ; \mathrm{C} 2-\mathrm{C} 3$ 1.314(4) $\AA$ ). By contrast to cyclopropene $[7](\mathrm{OTf})_{2}$, the two phosphonio groups are located on the same carbon atom, which causes the second carbon atom on the periphery of the allenic structure to be substituted by two mesityl groups. The angle between $\left[\left(\mathrm{PPh}_{3}\right)^{+}{ }_{2}-\mathrm{C}=\right]$ and $\left[(\mathrm{Mes})_{2}-\mathrm{C}=\right]$ planes deviates from the orthogonality by about $10.38^{\circ}$ certainly for steric and electrostatic constraints between the two bulky phosphonio moities as illustrated by the angle value $\left(\mathrm{P} 1-\mathrm{C} 1-\mathrm{P} 1 ' 123.33(14)^{\circ}\right)$. The corresponding 
angle involving the two mesityl rings $\left(\mathrm{C} 4-\mathrm{C} 3-\mathrm{C} 4{ }^{\prime} 119.9(2)^{\circ}\right)$ is very close to the ideal value $(\mathrm{ca}$. $\left.120.0^{\circ}\right)$
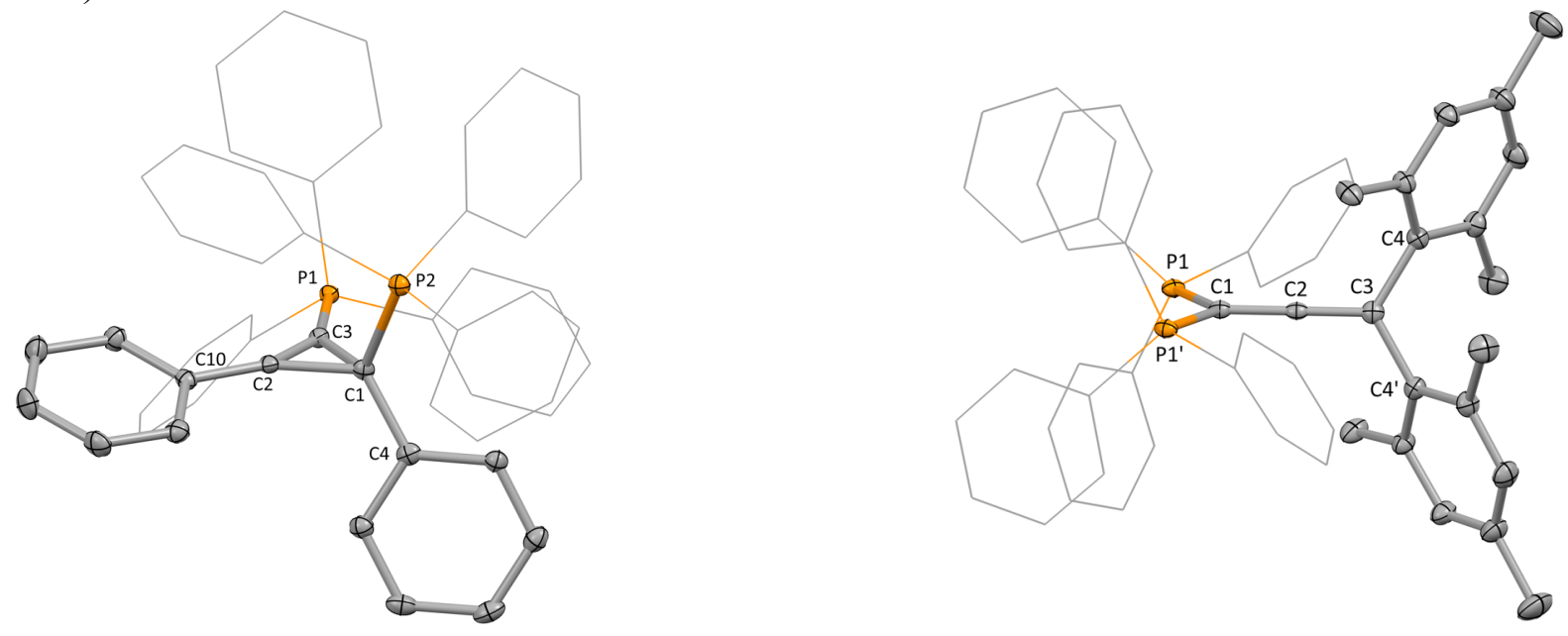

Figure 3. Perspective views of the cationic part of bis(phosphonium) derivatives [7](OTf $)_{2}($ left $)$ and $[8](\mathrm{OTf})_{2}$ (right) with thermal ellipsoids drawn at the $30 \%$ probability level (for clarity, the $\mathrm{H}$ atoms are omitted). Selected bond distances $(\AA)$ and angles $\left({ }^{\circ}\right)$ : [7](OTf): C1-P2 1.853(3), C3-P1 1.765(3), C1-C2 1.525(4), C1-C3 1.540(4), C2-C3 1.307(4), P1-C3-C1 147.6(2), P1-C3-C2 148.3(2), P2-C1-C2 112.83(18), P2-C1-C3 115.09(19), C2-C1-C3 50.50(17), C1-C2-C3 65.4(2), C1-C3-C2 64.1(2); [8](OTf): C1-P1 1.8357(13), C1-C2 1.325(4), C2-C3 1.314(4), C3-C4 1.511(2), $\quad \mathrm{C} 1-\mathrm{C} 2-\mathrm{C} 3$ 179.991, $\quad \mathrm{P} 1-\mathrm{C} 1-\mathrm{C} 2$ 118.33(7), $\mathrm{P} 1-\mathrm{C} 1-\mathrm{P} 1{ }^{\prime} \quad 123.33(14), \quad \mathrm{C} 2-\mathrm{C} 3-\mathrm{C} 4$ 120.03(11), C4-C3-C4’ 119.9(2).

The two different structures obtained by modifying only a substituent ( $\mathrm{Ph} v s \mathrm{Mes})$ on the starting cyclopropene raise questions about the mechanism of formation of bis(phosphonium) salts [7-8](OTf $)_{2}$. Assuming in both series an equilibrium between the two covalently bonded cationic chlorocyclopropenes $[\mathbf{5}-\mathbf{6}] \mathrm{Cl}$ and $[\mathbf{5 a}-\mathbf{6 a}] \mathrm{Cl}$ via triphenylphosphoniocyclopropenium intermediate, ${ }^{[15]}$ the formation of bis(phosphonium) salts $[7-8](\mathrm{OTf})_{2}$ can be tentatively rationalized by the existence of steric and electrostatic constraints.

In the case of 1,2-diphenyl substituted cyclopropene [5] Cl, the sterically demanding $\mathrm{PPh}_{3}$ nucleophile would preferentially react at the $\mathrm{C}-\mathrm{Ph}$ positions (Scheme 3, pathway a) minimizing thus the electrostatic repulsion between the two phosphonio groups, and affording the dicationic cyclopropene $[7](\mathrm{OTf})_{2}$ in a single step. Although a priori less likely, we can not exclude the reaction pathway $\mathrm{b}$ that involves the nucleophilic attack of $\mathrm{PPh}_{3}$ to the carbon atom bearing the phosphonium 
group. The corresponding bis(phosphonium) salt $[\mathbf{5 b}](\mathrm{OTf})_{2}$ would then give the cyclopropene $[7](\mathrm{OTf})_{2}$ via the highly constrained bicyclic intermediate $[\mathbf{5 c}](\mathrm{OTf})_{2}$ which formally accounts for the migration of a phosphonio group..$^{[16]}$

In the case of 1,2-mesityl substituted cyclopropene [6]Cl, the nucleophilic attack of $\mathrm{PPh}_{3}$ would not take place at the C-Mes carbon atoms for steric reasons, preferring to form the gem(triphenylphosphonio) cyclopropene $[\mathbf{6 b}](\mathrm{OTf})_{2}$. As reported for sterically encumbered cyclopropenes such as tetrakis(trimethylsilyl)cyclopropenes, ${ }^{[17]}$ we assume that the electrostatic constrained 3,3-bis(phosphonio)cyclopropene $[\mathbf{6 b}](\mathrm{OTf})_{2}$ would rearrange spontaneously by ring opening to the transient vinylcarbene $[\mathbf{6 c}](\mathrm{OTf})_{2}$ followed by a 1,2-shift of a mesityl group to the carbenic center affording finally the experimentally isolated allene $[8](\mathrm{OTf})_{2}$ (Scheme 3). Similar rearrangement was also evidenced by reacting bulky tris(alkylthio)cyclopropeniums with phosphanes via the formation of unstable 3-phosphoniocyclopropenes. ${ }^{[18]}$

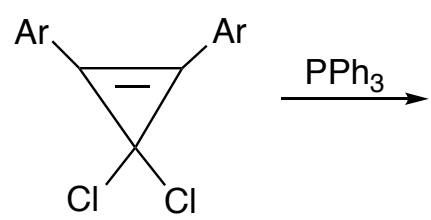

3-4

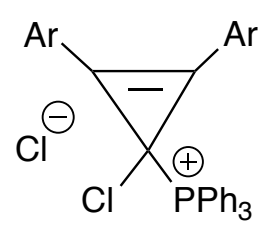

$\mathrm{Ar}=\mathrm{Ph},[5] \mathrm{Cl}$

$\mathrm{Ar}=\mathrm{Mes},[6] \mathrm{Cl}$
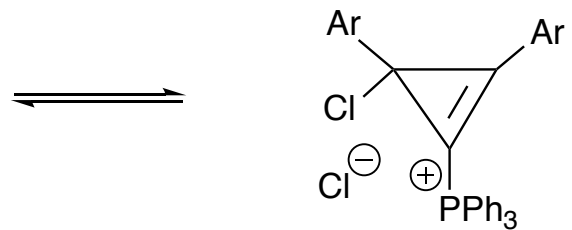

$\mathrm{Ar}=\mathrm{Ph},[\mathbf{5} \mathbf{a}] \mathrm{Cl}$

$\mathrm{Ar}=\mathrm{Mes},[6 \mathbf{6}] \mathrm{Cl}$

\begin{tabular}{c|c}
$\mathrm{PPh}_{3}$ & (a) \\
$\mathrm{Me}_{3} \mathrm{SiOTf}$ & $\mathrm{Ar}=\mathrm{Ph}$
\end{tabular}

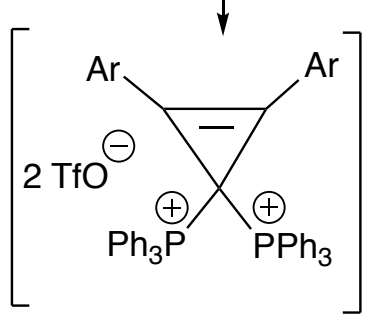

[5b-6b](OTf) 2 Ar $=$ Mes<smiles>CC(C)=C([Pb])[Pb](=O)c1ccccc1</smiles>

\section{(b)} $\overrightarrow{\mathrm{Ar}}=\mathrm{Ph}$

1,2-Mes

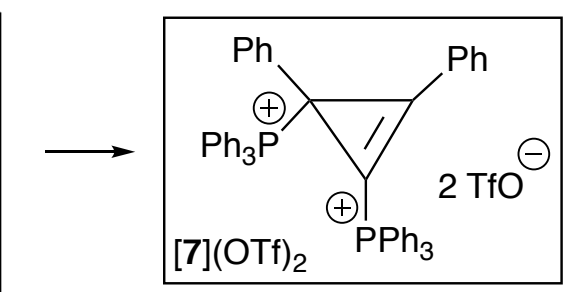

$[5 c](O T f)_{2}$

$[6 \mathrm{c}](\mathrm{OTf})_{2}$

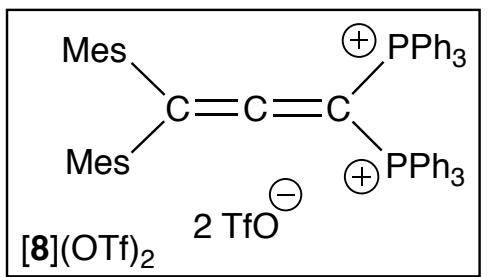

Scheme 3. Proposed mechanisms for the formation of bis(phosphonium) salts $[7-8](\mathrm{OTf})_{2}$ from corresponding 3-phosphoniocyclopropenes [5-6]Cl. All isolated products are framed. 
The mechanism of formation of cyclopropene [7](OTf $)_{2}$ was experimentally supported by the slow hydrolysis of 3-phosphoniocyclopropene [5] Cl to the vinyl phosphonium [9] Cl, the latter salt being formed in $75 \%$ yield after one day in wet $\mathrm{CH}_{2} \mathrm{Cl}_{2}$. As for [7](OTf) probably involve the cyclopropene isomer $[\mathbf{5 a}] \mathrm{Cl}$ which would undergo nucleophilic attack of a hydroxide ion at the $\mathrm{C}-\mathrm{Ph}$ position to form the hydroxycyclopropene $[\mathbf{5 d}] \mathrm{Cl}$ followed by ring opening and hydrogen migration (Scheme 4, right). ${ }^{[19]}$ The vinyl phosphonium [9]Cl obtained in a fully stereospecific manner was characterized by multi-nuclear NMR spectroscopy $\left(\delta_{\mathrm{P}} 15.9 \mathrm{ppm}\right)^{[\mathbf{2 0}]}$ and subjected to X-ray diffraction analysis from colorless crystals deposited from a $\mathrm{CH}_{2} \mathrm{Cl}_{2} / \mathrm{Et}_{2} \mathrm{O}$ mixture at room temperature (Figure 4). $\left.{ }^{[12}\right]$ The Z-configuration of [9]Cl was mainly attributed to attractive $\mathrm{P}^{+} / \mathrm{O}^{-}$electrostatic interactions.

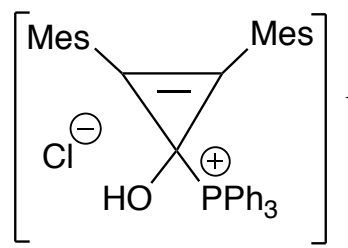

$[6 \mathrm{~d}] \mathrm{Cl}$

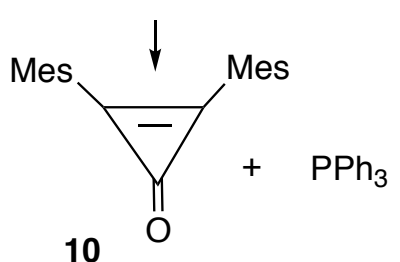

$$
\frac{\mathrm{H}_{2} \mathrm{O}}{\mathrm{Ar}=\mathrm{Mes}}
$$<smiles>C=CC1=C([Al])C1(Cl)[Pb]</smiles>

$\mathrm{Ar}=\mathrm{Ph},[5] \mathrm{Cl}$ $\mathrm{Ar}=\mathrm{Mes},[6] \mathrm{Cl}$

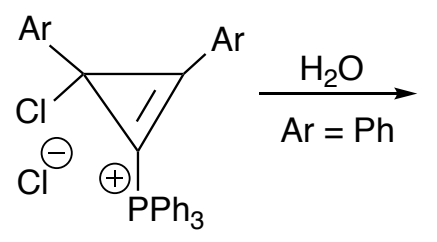

$\mathrm{Ar}=\mathrm{Ph},[5 \mathrm{a}] \mathrm{Cl}$ $\mathrm{Ar}=\mathrm{Mes},[6 \mathrm{a}] \mathrm{Cl}$

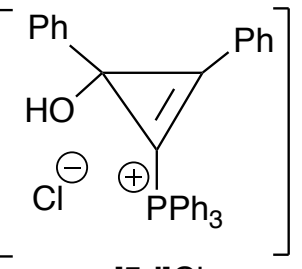

$[5 \mathrm{~d}] \mathrm{Cl}$

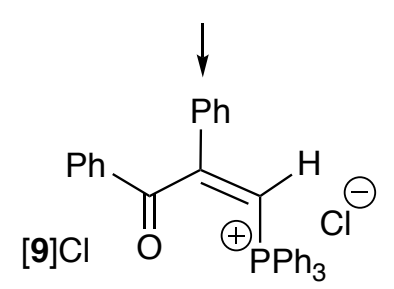

Scheme 4. Proposed mechanisms for the formation of vinyl phosphonium [9]Cl and 1,2dimesitylcyclopropenone 10 from hydrolysis of 3-phosphoniocyclopropenes [5-6]Cl. 


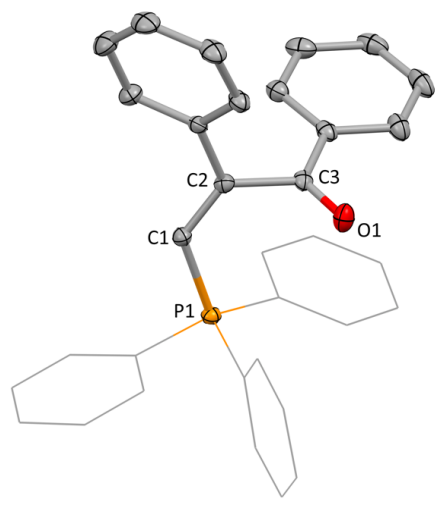

Figure 4. Perspective view of the cationic part of vinyl phosphonium [9]Cl with thermal ellipsoids drawn at the $30 \%$ probability level (for clarity, the H atoms are omitted). Selected bond distances $(\AA)$ and angles $\left(^{\circ}\right)$ : $\mathrm{C} 1-\mathrm{P} 1$ 1.788(2), $\mathrm{C} 1-\mathrm{C} 2$ 1.336(3), $\mathrm{C} 2-\mathrm{C} 3$ 1.513(3), $\mathrm{C} 3-\mathrm{O} 1$ 1.212(3), P1-C1-C2 125.32(18), C1-C2-C3 123.2(2), C2-C3-O1 119.3(2).

The 3-triphenylphosphoniocyclopropene $[6] \mathrm{Cl}$ was found to be relatively more stable towards hydrolysis. However, after few days in wet $\mathrm{CH}_{2} \mathrm{Cl}_{2}$, the concomitant formation of 1,2dimesitylcyclopropenone 10 and $\mathrm{PPh}_{3}$ was evidenced by ${ }^{31} \mathrm{P}$ and ${ }^{1} \mathrm{H}$ NMR spectroscopy (Scheme 4, left). ${ }^{[21]}$ This reactivity is in agreement with the mechanism proposed for the formation of bis(phosphonium) salt $[\mathbf{8}](\mathrm{OTf})_{2}$. The hydroxide nucleophile would not react indeed at the C-Mes carbon atoms for steric reasons, but at the $\mathrm{C}-\mathrm{PPh}_{3}{ }^{+}$position yielding the 3-hydroxycyclopropene [6d]Cl which would then stabilize by elimination of $\mathrm{PPh}_{3}$ and formation of 1,2dimesitylcyclopropenone $\mathbf{1 0 .}$

\section{Conclusions}

The outcome of the reaction between a neutral nucleophile such as triphenylphosphine and an electrophilic chlorocyclopropenium salt vs dichlorocyclopropene depends on the nature of cyclopropenyl substituents. While strongly $\pi$-donating amino groups stabilize the cationic cyclopropenium form, weaker $\pi$-donating aryl groups favor the neutral cyclopropenic form as demonstrated with the formation of 3-triphenylphosphonio-1,2-diarylcyclopropenes [4-5]Cl. When treating with a second equivalent of nucleophile, aryl substituents of cyclopropenes [4-5]Cl play an additional role, namely either the conservation of the cyclic structure to give the 1,3bis(phosphonio)cyclopropene [7](OTf $)_{2}$ if the substituent is a phenyl group or spontaneous ringopening into the linear 3,3-bis(phosphonio)allene $[8](\mathrm{OTf})_{2}$ if the substituent is larger, such as a 
mesityl group. The mechanism of formation of these two unprecedented bis(phosphonium) salts [7$\mathbf{8}](\mathrm{OTf})_{2}$ based on an isomeric backbone of general formula $\left[\mathrm{Ar}_{2} \mathrm{C}_{3}\left(\mathrm{PPh}_{3}\right)_{2}\right]^{2+}(\mathrm{OTf})^{2-}$ was mainly rationalized by the existence of steric and electrostatic constraints. The generalization of this methodology to other cyclopropenium salt precursors and phosphine nucleophiles deserves to be investigated, thus opening up prospects for the preparation of highly electrophilic species that could act as Lewis acid initiators in organocatalysis.

\section{Experimental Section}

General Remarks. All manipulations were performed under an inert atmosphere of dry nitrogen by using standard vacuum line and Schlenk tube techniques. Dry and oxygen-free organic solvents (THF, $\mathrm{Et}_{2} \mathrm{O}, \mathrm{CH}_{2} \mathrm{Cl}_{2}$, toluene, pentane) were obtained using a LabSolv (Innovative Technology) solvent purification system. Acetonitrile was dried and distilled over $\mathrm{CaH}_{2}$ under argon. All other reagentgrade chemicals were purchased from commercial sources and used as received. ${ }^{1} \mathrm{H},{ }^{31} \mathrm{P}$, and ${ }^{13} \mathrm{C}$ NMR spectra were obtained on Bruker Avance 400 and Avance III HD 400 spectrometers. NMR chemical shifts $\delta$ are in ppm, with positive values to high frequency relative to the tetramethylsilane reference for ${ }^{1} \mathrm{H}$ and ${ }^{13} \mathrm{C}$ and to $\mathrm{H}_{3} \mathrm{PO}_{4}$ for ${ }^{31} \mathrm{P}$. If necessary, additional information on the carbon signal attribution was obtained using ${ }^{13} \mathrm{C}\left\{{ }^{1} \mathrm{H},{ }^{31} \mathrm{P}\right\}, J$-modulated spin-echo (JMOD) ${ }^{13} \mathrm{C}\{1 \mathrm{H}\},{ }^{1} \mathrm{H}-{ }^{13} \mathrm{C}$ HMQC, and/or HMBC experiments. Mass spectra (ESI mode) were obtained using a Xevo G2 QTof (Waters) spectrometer and were performed by the mass spectrometry service of the "Institut de Chimie de Toulouse". 3-chloro-1,2-bis(diisopropylamino)cyclopropenium salt [1](OTf) was prepared according to a previously described procedure. ${ }^{[11]} 3,3$-dichloro-1,2-diphenylcyclopropene 3, and 3,3dichloro-1,2-dimesitylcyclopropene $\mathbf{4}$ were prepared according to a previously described procedure. ${ }^{[13]}$

\section{3-triphenylphosphonio-1,2-bis(diisopropylamino)cyclopropenium bis(triflate) [2](OTf) 2}

Method a: Chlorocyclopropenium salt [1](OTf) (0.22 g, $0.52 \mathrm{mmol})$, triphenylphosphine $(0.20 \mathrm{~g}, 0.78$ $\mathrm{mmol})$ and sodium trifluoromethanesulfonate $(0.10 \mathrm{~g}, 0.57 \mathrm{mmol})$ were dissolved in THF $(10 \mathrm{~mL})$, and the suspension was stirred at $60{ }^{\circ} \mathrm{C}$ for 16 hours. The solvent was evaporated under vacuum, and the solid residue was dissolved in $\mathrm{CH}_{2} \mathrm{Cl}_{2}(10 \mathrm{~mL})$ and filtered. After evaporation of the solvent, the solid was washed with THF $(10 \mathrm{~mL})$ affording [2](OTf $)_{2}$ as a white microcrystalline solid $(0.39 \mathrm{~g}$, 
$95 \%)$.

Method $b$ : To a solution of chlorocyclopropenium salt [1](OTf) $(0.15 \mathrm{~g}, 0.36 \mathrm{mmol})$ in $\mathrm{CH}_{2} \mathrm{Cl}_{2}(5 \mathrm{~mL})$ was added triphenylphosphine $(0.10 \mathrm{~g}, 0.39 \mathrm{mmol})$ and trimethylsilyl trifluoromethanesulfonate $(71$ $\mu 1,0.39 \mathrm{mmol}$ ) at $-40{ }^{\circ} \mathrm{C}$. The solution was then stirred at room temperature for 2 hours. The solvent was evaporated under vacuum, and the solid residue was washed with THF (10 mL) affording a white microcrystalline solid $(0.25 \mathrm{~g}, 90 \%)$. Recrystallization at room temperature from $\mathrm{CH}_{2} \mathrm{Cl}_{2} / \mathrm{Et}_{2} \mathrm{O}$ gave $[2](\mathrm{OTf})_{2}$ as colorless crystals.

${ }^{1} \mathrm{H}$ NMR $\left(\mathrm{CD}_{3} \mathrm{CN}, 25^{\circ} \mathrm{C}\right): \delta=0.81\left(\mathrm{~d}, J_{\mathrm{HH}}=7.0 \mathrm{~Hz}, 12 \mathrm{H}, \mathrm{CH}_{3}\right), \delta=1.45\left(\mathrm{~d}, J_{\mathrm{HH}}=7.0 \mathrm{~Hz}, 12 \mathrm{H}, \mathrm{CH}_{3}\right)$, 3.47 (sept, $\left.J_{\mathrm{HH}}=7.0 \mathrm{~Hz}, 2 \mathrm{H}, \mathrm{CH}\right), 4.30$ (sept, $\left.J_{\mathrm{HH}}=7.0 \mathrm{~Hz}, 2 \mathrm{H}, \mathrm{CH}\right), 7.84-7.89$ (m, 6H, Har), 7.96$8.03\left(\mathrm{~m}, 9 \mathrm{H}, \mathrm{H}_{\mathrm{ar}}\right) .{ }^{13} \mathrm{C} \mathrm{NMR}\left(\mathrm{CD}_{3} \mathrm{CN}, 25^{\circ} \mathrm{C}\right): \delta=20.1\left(\mathrm{~s}, \mathrm{CH}_{3}\right), 21.5\left(\mathrm{~s}, \mathrm{CH}_{3}\right), 56.6(\mathrm{brs}, \mathrm{CH}), 83.6(\mathrm{~d}$, $\left.J_{\mathrm{CP}}=105.6 \mathrm{~Hz}, \mathrm{C}\right), 116.5\left(\mathrm{~d}, J_{\mathrm{CP}}=93.6 \mathrm{~Hz}, \mathrm{C}\right), 122.1\left(\mathrm{q}, J_{\mathrm{CF}}=321.9 \mathrm{~Hz}, \mathrm{CF}_{3} \mathrm{SO}_{3}\right), 132.1\left(\mathrm{~d}, J_{\mathrm{CP}}=\right.$ $13.1 \mathrm{~Hz}, \mathrm{CH}_{\mathrm{ar}}$ ), 135.9 (d, $\left.J_{\mathrm{CP}}=12.1 \mathrm{~Hz}, \mathrm{CH}_{\mathrm{ar}}\right), 137.9$ (d, $J_{\mathrm{CP}}=3.0 \mathrm{~Hz}, \mathrm{CH}_{\mathrm{ar}}$ ), 140.9 (brs, C). ${ }^{31} \mathrm{P}$ NMR $\left(\mathrm{CD}_{3} \mathrm{CN}, 25^{\circ} \mathrm{C}\right): \delta=9.3$ ppm. MS $\left(\mathrm{ES}^{+}\right): \mathrm{m} / z: 647.2\left[\mathrm{M}^{+}\right]$. HRMS $\left(\mathrm{ES}^{+}\right)$: calcd for $\mathrm{C}_{34} \mathrm{H}_{43} \mathrm{~N}_{2} \mathrm{O}_{3} \mathrm{SF}_{3} \mathrm{P}$ 647.2684; found 647.2677.

\section{3-chloro-3-triphenylphosphonio-1,2-diphenylcyclopropene chloride [5] Cl}

To a solution of 3,3-dichloro-1,2-diphenylcyclopropene $3(0.11 \mathrm{~g}, 0.42 \mathrm{mmol})$ in $\mathrm{CH}_{2} \mathrm{Cl}_{2}(5 \mathrm{~mL})$ was added triphenylphosphine $(0.12 \mathrm{~g}, 0.46 \mathrm{mmol})$ at room temperature, and the solution was then stirred for 2 hours. The solvent was evaporated under vacuum, and the solid residue was washed with THF $(10 \mathrm{~mL})$ affording $[5] \mathrm{Cl}$ as a white air sensitive solid $(0.20 \mathrm{~g}, 90 \%)$.

${ }^{1} \mathrm{H}$ NMR $\left(\mathrm{CD}_{3} \mathrm{CN}, 25^{\circ} \mathrm{C}\right): \delta=7.49-7.55\left(\mathrm{~m}, 4 \mathrm{H}, \mathrm{H}_{\mathrm{ar}}\right), 7.56-7.63\left(\mathrm{~m}, 6 \mathrm{H}, \mathrm{H}_{\mathrm{ar}}\right), 7.69-7.81\left(\mathrm{~m}, 12 \mathrm{H}, \mathrm{H}_{\mathrm{ar}}\right)$, 7.89-7.93 (m, $\left.3 \mathrm{H}, \mathrm{H}_{\mathrm{ar}}\right) .{ }^{13} \mathrm{C} \mathrm{NMR}\left(\mathrm{CD}_{3} \mathrm{CN}, 25^{\circ} \mathrm{C}\right): \delta=47.2\left(\mathrm{~d}, J_{\mathrm{CP}}=111.7 \mathrm{~Hz}, \mathrm{C}\right), 116.0(\mathrm{~s}, \mathrm{C}), 117.7$ $\left(\mathrm{d}, J_{\mathrm{CP}}=86.5 \mathrm{~Hz}, \mathrm{C}\right), 123.5\left(\mathrm{~d}, J_{\mathrm{CP}}=2.0 \mathrm{~Hz}, \mathrm{C}\right), 130.7\left(\mathrm{~s}, \mathrm{CH}_{\mathrm{ar}}\right), 130.8\left(\mathrm{~s}, \mathrm{CH}_{\mathrm{ar}}\right), 131.5\left(\mathrm{~d}, J_{\mathrm{CP}}=12.1\right.$ $\left.\mathrm{Hz}, \mathrm{CH}_{\mathrm{ar}}\right), 133.4\left(\mathrm{~s}, \mathrm{CH}_{\mathrm{ar}}\right), 135.7$ (d, $\left.J_{\mathrm{CP}}=10.1 \mathrm{~Hz}, \mathrm{CH}_{\mathrm{ar}}\right), 136.9$ (d, $\left.J_{\mathrm{CP}}=3.0 \mathrm{~Hz}, \mathrm{CH}_{\mathrm{ar}}\right) .{ }^{31} \mathrm{P} \mathrm{NMR}$ $\left(\mathrm{CD}_{3} \mathrm{CN}, 25^{\circ} \mathrm{C}\right): \delta=29.1 \mathrm{ppm}$. MS $\left(\mathrm{ES}^{+}\right): \mathrm{m} / z: 487.1\left[\mathrm{M}^{+}\right]$. HRMS $\left(\mathrm{ES}^{+}\right)$: calcd for $\mathrm{C}_{33} \mathrm{H}_{25} \mathrm{ClP}$ 487.1382; found 487.1381.

\section{3-chloro-3-triphenylphosphonio-1,2-dimesitylcyclopropene chloride [6]Cl}

To a solution of 3,3-dichloro-1,2-dimesitylcyclopropene $4(0.10 \mathrm{~g}, 0.29 \mathrm{mmol})$ in $\mathrm{CH}_{2} \mathrm{Cl}_{2}(5 \mathrm{~mL})$ was added triphenylphosphine $(83 \mathrm{mg}, 0.32 \mathrm{mmol}$ ) at room temperature, and the solution was then stirred 
for 2 hours. The solvent was evaporated under vacuum, and the solid residue was washed with THF $(10 \mathrm{~mL})$ affording $[6] \mathrm{Cl}$ as a white air sensitive solid $(0.17 \mathrm{~g}, 95 \%)$.

${ }^{1} \mathrm{H}$ NMR $\left(\mathrm{CD}_{3} \mathrm{CN}, 25^{\circ} \mathrm{C}\right): \delta=1.78\left(\mathrm{~s}, 12 \mathrm{H}, \mathrm{CH}_{3}\right), 2.34\left(\mathrm{~s}, 6 \mathrm{H}, \mathrm{CH}_{3}\right), 7.04\left(\mathrm{~s}, 4 \mathrm{H}, \mathrm{H}_{\mathrm{ar}}\right), 7.60-7.70$ (m, $\left.12 \mathrm{H}, \mathrm{H}_{\mathrm{ar}}\right), 7.89-7.94\left(\mathrm{~m}, 3 \mathrm{H}, \mathrm{H}_{\mathrm{ar}}\right) \cdot{ }^{13} \mathrm{C} \mathrm{NMR}\left(\mathrm{CD}_{3} \mathrm{CN}, 25^{\circ} \mathrm{C}\right): \delta=21.3\left(\mathrm{~s}, \mathrm{CH}_{3}\right), 52.4\left(\mathrm{~d}, J_{\mathrm{CP}}=109.7\right.$ Hz, C), 117.1 (d, $\left.J_{\mathrm{CP}}=87.5 \mathrm{~Hz}, \mathrm{C}\right), 119.9$ (s, C), 121.9 (d, $\left.J_{\mathrm{CP}}=3.0 \mathrm{~Hz}, \mathrm{C}\right), 130.7$ (s, $\left.\mathrm{CH}_{\mathrm{ar}}\right), 131.3$ (d, $\left.J_{\mathrm{CP}}=12.1 \mathrm{~Hz}, \mathrm{CH}_{\mathrm{ar}}\right), 136.4\left(\mathrm{~d}, J_{\mathrm{CP}}=10.1 \mathrm{~Hz}, \mathrm{CH}_{\mathrm{ar}}\right), 136.9\left(\mathrm{~d}, J_{\mathrm{CP}}=3.0 \mathrm{~Hz}, \mathrm{CH}_{\mathrm{ar}}\right), 140.1(\mathrm{~s}, \mathrm{C}), 143.4$ (s, C). ${ }^{31} \mathrm{P} \mathrm{NMR}\left(\mathrm{CD}_{3} \mathrm{CN}, 25^{\circ} \mathrm{C}\right): \delta=30.4 \mathrm{ppm} . \mathrm{MS}\left(\mathrm{ES}^{+}\right): m / z: 571.2\left[\mathrm{M}^{+}\right]$. HRMS $\left(\mathrm{ES}^{+}\right)$: calcd for $\mathrm{C}_{39} \mathrm{H}_{37} \mathrm{ClP}$ 571.2321; found 571.2316.

\section{1,3-bis(triphenylphosphonio)-2,3-diphenylcyclopropene bis(triflate) [7](OTf $)_{2}$}

Method a: To a solution of 3,3-dichloro-1,2-diphenylcyclopropene $3(0.17 \mathrm{~g}, 0.65 \mathrm{mmol})$ in $\mathrm{CH}_{2} \mathrm{Cl}_{2}$ $(10 \mathrm{~mL})$ was added triphenylphosphine $(0.43 \mathrm{~g}, 1.62 \mathrm{mmol})$ and trimethylsilyl trifluoromethanesulfonate $(248 \mu \mathrm{l}, 1.37 \mathrm{mmol})$ at $-40{ }^{\circ} \mathrm{C}$. The resulting solution was then stirred at room temperature for 12 hours. The solvent was evaporated under vacuum, and the solid residue was washed with THF $(20 \mathrm{~mL})$ affording a white solid $(0.59 \mathrm{~g}, 89 \%)$. Recrystallization at $-20{ }^{\circ} \mathrm{C}$ from $\mathrm{CH}_{2} \mathrm{Cl}_{2} / \mathrm{Et}_{2} \mathrm{O}$ gave [7](OTf $)_{2}$ as colorless crystals.

Method b: To a solution of 3-phosphoniocyclopropene [5] Cl $(0.10 \mathrm{~g}, 0.19 \mathrm{mmol})$ in $\mathrm{CH}_{2} \mathrm{Cl}_{2}(10 \mathrm{~mL})$ was added triphenylphosphine $(0.06 \mathrm{~g}, 0.21 \mathrm{mmol})$ and trimethylsilyl trifluoromethanesulfonate $(73$ $\mu 1, \quad 0.40 \mathrm{mmol})$ at $-40{ }^{\circ} \mathrm{C}$. The resulting solution was then stirred at room temperature for 3 hours. The solvent was evaporated under vacuum, and the solid residue was washed with THF (20 mL) affording [7](OTf $)_{2}$ as a white solid $(0.18 \mathrm{~g}, 96 \%)$.

${ }^{1} \mathrm{H}$ NMR ( $\left.\mathrm{CD}_{3} \mathrm{CN}, 25^{\circ} \mathrm{C}\right): \delta=7.15-7.30\left(\mathrm{~m}, 12 \mathrm{H}, \mathrm{H}_{\mathrm{ar}}\right), 7.34-7.45\left(\mathrm{~m}, 10 \mathrm{H}, \mathrm{H}_{\mathrm{ar}}\right), 7.50-7.57(\mathrm{~m}, 6 \mathrm{H}$, $\left.\mathrm{H}_{\mathrm{ar}}\right)$, 7.62-7.69 (m, 6H, $\left.\mathrm{H}_{\mathrm{ar}}\right), 7.83-7.89(\mathrm{~m}, 3 \mathrm{H}, \mathrm{H} \mathrm{ar}), 7.92-7.98\left(\mathrm{~m}, 3 \mathrm{H}, \mathrm{H}_{\mathrm{ar}}\right) .{ }^{13} \mathrm{C} \mathrm{NMR}\left(\mathrm{CD}_{3} \mathrm{CN}\right.$, $\left.25^{\circ} \mathrm{C}\right): \delta=39.3\left(\mathrm{~d}, J_{\mathrm{CP}}=74.4 \mathrm{~Hz}, \mathrm{C}\right), 98.8\left(\mathrm{dd}, J_{\mathrm{CP}}=5.5\right.$ and $\left.103.1 \mathrm{~Hz}, \mathrm{C}\right), 116.4\left(\mathrm{~d}, J_{\mathrm{CP}}=94.6 \mathrm{~Hz}\right.$, C), $117.3\left(\mathrm{~d}, J_{\mathrm{CP}}=84.5 \mathrm{~Hz}, \mathrm{C}\right), 122.1\left(\mathrm{q}, J_{\mathrm{CF}}=320.9 \mathrm{~Hz}, \mathrm{CF}_{3} \mathrm{SO}_{3}\right), 122.8(\mathrm{~s}, \mathrm{C}), 130.1\left(\mathrm{~d}, J_{\mathrm{CP}}=4.0\right.$ $\left.\mathrm{Hz}, \mathrm{CH}_{\mathrm{ar}}\right), 131.0\left(\mathrm{~s}, \mathrm{CH}_{\mathrm{ar}}\right), 131.1\left(\mathrm{~s}, \mathrm{CH}_{\mathrm{ar}}\right), 131.3\left(\mathrm{~s}, \mathrm{CH}_{\mathrm{ar}}\right), 131.7$ (d, $\left.J_{\mathrm{CP}}=12.1 \mathrm{~Hz}, \mathrm{CH}_{\mathrm{ar}}\right), 132.2(\mathrm{~d}$, $\left.J_{\mathrm{CP}}=13.1 \mathrm{~Hz}, \mathrm{CH}_{\mathrm{ar}}\right), 133.4\left(\mathrm{~s}, \mathrm{CH}_{\mathrm{ar}}\right), 134.7\left(\mathrm{~d}, J_{\mathrm{CP}}=12.1 \mathrm{~Hz}, \mathrm{CH}_{\mathrm{ar}}\right), 135.7\left(\mathrm{~d}, J_{\mathrm{CP}}=10.1 \mathrm{~Hz}, \mathrm{CH}_{\mathrm{ar}}\right)$, $136.9\left(\mathrm{~s}, \mathrm{CH}_{\mathrm{ar}}\right), 137.0\left(\mathrm{~d}, J_{\mathrm{CP}}=3.0 \mathrm{~Hz}, \mathrm{CH}_{\mathrm{ar}}\right), 137.7$ (d, $\left.J_{\mathrm{CP}}=3.0 \mathrm{~Hz}, \mathrm{CH}_{\mathrm{ar}}\right), 144.8$ (t, $\left.J_{\mathrm{CP}}=3.0 \mathrm{~Hz}, \mathrm{C}\right)$. ${ }^{31} \mathrm{P}$ NMR $\left(\mathrm{CD}_{3} \mathrm{CN}, 25^{\circ} \mathrm{C}\right): \delta=15.0\left(\mathrm{~d}, J_{\mathrm{PP}}=10.5 \mathrm{~Hz}\right), 30.3\left(\mathrm{~d}, J_{\mathrm{PP}}=10.5 \mathrm{~Hz}\right) \mathrm{ppm} . \mathrm{MS}\left(\mathrm{ES}^{+}\right): m / z$ : 863.2 [M+]. HRMS (ES ${ }^{+}$): calcd for $\mathrm{C}_{52} \mathrm{H}_{40} \mathrm{O}_{3} \mathrm{SF}_{3} \mathrm{P}_{2}$ 863.2125; found 863.2109. 


\section{3,3-bis(triphenylphosphonio)-1,1-dimesitylallene bis(triflate) $[8](\mathrm{OTf})_{2}$}

Method a: To a solution of 3,3-dichloro-1,2-dimesitylcyclopropene 4 (0.29 g, $0.83 \mathrm{mmol})$ in $\mathrm{CH}_{2} \mathrm{Cl}_{2}$ $(15 \mathrm{~mL})$ was added triphenylphosphine $(0.55 \mathrm{~g}, 2.10 \mathrm{mmol})$ and trimethylsilyl trifluoromethanesulfonate $(319 \mu \mathrm{l}, 1.75 \mathrm{mmol})$ at $-40{ }^{\circ} \mathrm{C}$. The solution was then stirred at room temperature for 12 hours. The solvent was evaporated under vacuum, and the solid residue was washed with THF $(20 \mathrm{~mL})$ affording a white solid $(0.70 \mathrm{~g}, 75 \%)$. Recrystallization at room temperature from $\mathrm{CH}_{2} \mathrm{Cl}_{2} / \mathrm{Et}_{2} \mathrm{O}$ gave $[8](\mathrm{OTf})_{2}$ as colorless crystals.

Method b: To a solution of 3-phosphoniocyclopropene [6]Cl $(0.10 \mathrm{~g}, 0.16 \mathrm{mmol})$ in $\mathrm{CH}_{2} \mathrm{Cl}_{2}(10 \mathrm{~mL})$ was added triphenylphosphine $(0.05 \mathrm{~g}, 0.18 \mathrm{mmol})$ and trimethylsilyl trifluoromethanesulfonate $(63$ $\mu 1, \quad 0.35 \mathrm{mmol})$ at $-40{ }^{\circ} \mathrm{C}$. The resulting solution was then stirred at room temperature for 3 hours. The solvent was evaporated under vacuum, and the solid residue was washed with THF (20 mL) affording $[8](\mathrm{OTf})_{2}$ as a white solid $(0.15 \mathrm{~g}, 86 \%)$.

${ }^{1} \mathrm{H}$ NMR $\left(\mathrm{CD}_{3} \mathrm{CN}, 25^{\circ} \mathrm{C}\right): \delta=1.37\left(\mathrm{~s}, 12 \mathrm{H}, \mathrm{CH}_{3}\right), 2.34\left(\mathrm{~s}, 6 \mathrm{H}, \mathrm{CH}_{3}\right), 6.95\left(\mathrm{~s}, 4 \mathrm{H}, \mathrm{H}_{\mathrm{ar}}\right), 7.52-7.56(\mathrm{~m}$, $\left.12 \mathrm{H}, \mathrm{H}_{\mathrm{ar}}\right), 7.61-7.66\left(\mathrm{~m}, 12 \mathrm{H}, \mathrm{H}_{\mathrm{ar}}\right), 7.79-7.83\left(\mathrm{~m}, 6 \mathrm{H}, \mathrm{H}_{\mathrm{ar}}\right) .{ }^{13} \mathrm{C} \mathrm{NMR}\left(\mathrm{CD}_{3} \mathrm{CN}, 25^{\circ} \mathrm{C}\right): \delta=21.0(\mathrm{~s}$, $\left.\mathrm{CH}_{3}\right), 22.5\left(\mathrm{~s}, \mathrm{CH}_{3}\right), 75.7\left(\mathrm{t}, J_{\mathrm{CP}}=74.2 \mathrm{~Hz}, \mathrm{C}\right), 116.0(\mathrm{~m}, \mathrm{C})^{*}, 117.7\left(\mathrm{t}, J_{\mathrm{CP}}=13.2 \mathrm{~Hz}, \mathrm{C}\right), 122.2\left(\mathrm{q}, J_{\mathrm{CF}}\right.$ $\left.=320.8 \mathrm{~Hz}, \mathrm{CF}_{3} \mathrm{SO}_{3}\right), 126.6\left(\mathrm{t}, J_{\mathrm{CP}}=5.0 \mathrm{~Hz}, \mathrm{C}\right), 131.4\left(\mathrm{t}, J_{\mathrm{CP}}=6.7 \mathrm{~Hz}, \mathrm{CH}_{\mathrm{ar}}\right), 131.9\left(\mathrm{~s}, \mathrm{CH}_{\mathrm{ar}}\right), 136.7$ (t, $\left.J_{\mathrm{CP}}=5.0 \mathrm{~Hz}, \mathrm{CH}_{\mathrm{ar}}\right), 137.6\left(\mathrm{~s}, \mathrm{CH}_{\mathrm{ar}}\right), 138.0\left(\mathrm{t}, J_{\mathrm{CP}}=3.0 \mathrm{~Hz}, \mathrm{C}\right), 140.9(\mathrm{~s}, \mathrm{C}), 227.6\left(\mathrm{t}, J_{\mathrm{CP}}=3.0 \mathrm{~Hz}\right.$, C). ${ }^{31} \mathrm{P}$ NMR $\left(\mathrm{CD}_{3} \mathrm{CN}, 25^{\circ} \mathrm{C}\right): \delta=25.3 \mathrm{ppm} . \mathrm{MS}\left(\mathrm{ES}^{+}\right): \mathrm{m} / z: 947.3\left[\mathrm{M}^{+}\right]$. HRMS $\left(\mathrm{ES}^{+}\right)$: calcd for $\mathrm{C}_{58} \mathrm{H}_{52} \mathrm{O}_{3} \mathrm{SF}_{3} \mathrm{P}_{2}$ 947.3064; found 947.3076.

* This ${ }^{13} \mathrm{C}$ NMR signal corresponds to the chemical resonance of the $\mathrm{C}_{\mathrm{ipso}}$ carbon atoms of the $\mathrm{PPh}_{3}{ }^{+}$ groups. Since it is a second order system, the corresponding coupling constants $\left({ }^{1} J_{\mathrm{CP}}=88.0 \mathrm{~Hz},{ }^{3} J_{\mathrm{CP}}=\right.$ $0 \mathrm{~Hz},{ }^{2} J_{\mathrm{PP}}=42.0 \mathrm{~Hz}$ ) were determined by simulation using the software Mest Renova.

\section{3-oxo-1,2-diphenyl-prop-1-enyl-triphenylphosphonium chloride [9]Cl}

A solution of [5] $\mathrm{Cl}(0.10 \mathrm{~g}, 0.19 \mathrm{mmol})$ in wet $\mathrm{CH}_{2} \mathrm{Cl}_{2}(5 \mathrm{~mL})$ was stirred at room temperature for 1 day. After evaporation of the solvent under vacuum, the solid residue was washed with $\mathrm{Et}_{2} \mathrm{O}(20 \mathrm{~mL})$ affording a white solid $(0.07 \mathrm{~g}, 75 \%)$. Recrystallization at room temperature from $\mathrm{CH}_{2} \mathrm{Cl}_{2} / \mathrm{Et}_{2} \mathrm{O}$ gave [9] Cl as colorless crystals.

${ }^{1} \mathrm{H}$ NMR $\left(\mathrm{CD}_{3} \mathrm{CN}, 25^{\circ} \mathrm{C}\right): \delta=7.20-7.24\left(\mathrm{~m}, 2 \mathrm{H}, \mathrm{H}_{\mathrm{ar}}\right), 7.35-7.38\left(\mathrm{~m}, 2 \mathrm{H}, \mathrm{H}_{\mathrm{ar}}\right), 7.43\left(\mathrm{~d},{ }^{2} J_{\mathrm{HP}}=16.7 \mathrm{~Hz}\right.$, 1H, CHP), 7.48-7.56 (m, 10H, $\left.\mathrm{H}_{\mathrm{ar}}\right), 7.62-7.65\left(\mathrm{~m}, 2 \mathrm{H}, \mathrm{H}_{\mathrm{ar}}\right), 7.69-7.76\left(\mathrm{~m}, 9 \mathrm{H}, \mathrm{H}_{\mathrm{ar}}\right) .{ }^{13} \mathrm{C} \mathrm{NMR}$ 
$\left(\mathrm{CD}_{3} \mathrm{CN}, 25^{\circ} \mathrm{C}\right): \delta=110.1\left(\mathrm{~d}, J_{\mathrm{CP}}=89.5 \mathrm{~Hz}, \mathrm{CH}\right), 118.9\left(\mathrm{~d}, J_{\mathrm{CP}}=91.5 \mathrm{~Hz}, \mathrm{C}\right), 128.6\left(\mathrm{~s}, \mathrm{CH}_{\mathrm{ar}}\right), 129.4$ (s, $\left.\mathrm{CH}_{\mathrm{ar}}\right), 130.4\left(\mathrm{~s}, \mathrm{CH}_{\mathrm{ar}}\right), 130.7\left(\mathrm{~d}, J_{\mathrm{CP}}=13.1 \mathrm{~Hz}, \mathrm{CH}_{\mathrm{ar}}\right), 130.8\left(\mathrm{~s}, \mathrm{CH}_{\mathrm{ar}}\right), 132.9\left(\mathrm{~s}, \mathrm{CH}_{\mathrm{ar}}\right), 135.2(\mathrm{~s}, \mathrm{C})$, $135.5\left(\mathrm{~d}, J_{\mathrm{CP}}=11.1 \mathrm{~Hz}, \mathrm{CH}_{\mathrm{ar}}\right), 135.8\left(\mathrm{~s}, \mathrm{CH}_{\mathrm{ar}}\right), 136.1\left(\mathrm{~d}, J_{\mathrm{CP}}=3.0 \mathrm{~Hz}, \mathrm{CH}_{\mathrm{ar}}\right), 166.6\left(\mathrm{~d}, J_{\mathrm{CP}}=3.0 \mathrm{~Hz}\right.$, C), $194.9\left(\mathrm{~d}, J_{\mathrm{CP}}=6.0 \mathrm{~Hz}, \mathrm{CO}\right) .{ }^{31} \mathrm{P} \mathrm{NMR}\left(\mathrm{CD}_{3} \mathrm{CN}, 25^{\circ} \mathrm{C}\right): \delta=15.9 \mathrm{ppm}$. MS $\left(\mathrm{ES}^{+}\right): m / z: 469.2\left[\mathrm{M}^{+}\right]$. HRMS (ES ${ }^{+}$): calcd for $\mathrm{C}_{33} \mathrm{H}_{26} \mathrm{OP} 469.1721$; found 469.1726 .

\section{Hydrolysis of 3-chloro-3-triphenylphosphonio-1,2-dimesitylcyclopropene chloride [6]Cl}

A solution of $[6] \mathrm{Cl}(0.10 \mathrm{~g}, 0.34 \mathrm{mmol})$ in wet $\mathrm{CH}_{2} \mathrm{Cl}_{2}(5 \mathrm{~mL})$ was stirred at room temperature. After

3 days, ${ }^{31} \mathrm{P}$ and ${ }^{1} \mathrm{H}$ NMR spectroscopy indicate the quantitative formation of 1,2-dimesityl cyclopropenone 10 and $\mathrm{PPh}_{3}$. Their chemical identity was unambiguously confirmed by comparison with literature data. ${ }^{[21]}$

\section{Single-crystal X-ray diffraction analyses of $[2](\mathrm{OTf})_{2},[7](\mathrm{OTf})_{2},[8](\mathrm{OTf})_{2}$, and $[9] \mathrm{Cl}$}

Intensity data were collected at low temperature on an Apex2 Bruker (equipped with a $30 \mathrm{~W}$ air-cooled microfocus Mo source $(\lambda=0.71073 \AA)$ ) or an Oxford-Diffraction Gemini diffractometer (equipped with a $\mathrm{Cu}$ source $(\lambda=1.54180 \AA))$. The structures were solved using SUPERFLIP, ${ }^{[22]}$ and refined by means of least-squares procedures using CRYSTALS. ${ }^{[23]}$ Atomic scattering factors were taken from the international tables for X-ray crystallography. All non-hydrogen atoms were refined anisotropically. All hydrogens atoms were placed geometrically and refined by using a riding model. For compound [9] Cl, it was not possible to resolve diffuse electron-density residuals (enclosed solvent molecules). Treatment with the SQUEEZE facility from PLATON (Spek, 1990) resulted in a smooth refinement. ${ }^{[24]}$ Since a few low order reflections are missing from the data set, the electron count will be underestimated. Thus, the values given for $\mathrm{D}($ calc), $\mathrm{F}(000)$ and the molecular weight are only valid for the ordered part of the structure. Absorption corrections were introduced using the program MULTISCAN. ${ }^{[25]}$ 


$$
[2](\mathrm{OTf})_{2} \quad[7](\mathrm{OTf})_{2} \quad[8](\mathrm{OTf})_{2} \quad[9] \mathrm{Cl}
$$

Empirical formula $\mathrm{C}_{36} \mathrm{H}_{45} \mathrm{Cl}_{2} \mathrm{~F}_{6} \mathrm{~N}_{2} \mathrm{O}_{6} \mathrm{PS}_{2} \mathrm{C}_{54} \mathrm{H}_{42} \mathrm{Cl}_{2} \mathrm{~F}_{6} \mathrm{O}_{6} \mathrm{P}_{2} \mathrm{~S}_{2} \mathrm{C}_{59} \mathrm{H}_{55} \mathrm{~F}_{6} \mathrm{O}_{7.50} \mathrm{P}_{2} \mathrm{~S}_{2} \quad \mathrm{C}_{33} \mathrm{H}_{26} \mathrm{ClOP}$

$\begin{array}{ccccc}\text { Formula mass } & 881.76 & 1097.90 & 1124.15 & 504.96 \\ \text { Crystal system } & \text { Triclinic } & \text { Triclinic } & \text { Monoclinic } & \text { Monoclinic } \\ \text { Space group } & \mathrm{P}-1 & \mathrm{P}-1 & \mathrm{C} 2 / \mathrm{c} & \mathrm{P}{ }_{1 / \mathrm{c}} \\ \mathrm{T}[\mathrm{K}] & 100 & 143 & 170 & 150 \\ a[\AA] & 12.3514(5) & 13.5665(10) & 24.4695(12) & 27.04340(4) \\ b[\AA] & 13.0626(5) & 13.9157(7) & 16.6341(7) & 10.09730(2) \\ c[\AA] & 14.9092(6) & 15.6326(7) & 17.9893(8) & 25.48880(4) \\ \alpha\left[^{\circ}\right] & 77.0138(18) & 82.648(4) & 90 & 90 \\ \beta\left[^{\circ}\right] & 66.5174(18) & 69.202(6) & 128.615(2) & 111.837(3) \\ \gamma\left[^{\circ}\right] & 71.8820(17) & 66.429(6) & 90 & 90 \\ V\left[^{\circledR}\right] & 2082.80(15) & 2528.4(3) & 5721.2(5) & 6460.68(12) \\ D_{c} & 1.406 & 1.442 & 1.302 & 1.038 \\ Z & 2 & 2 & 4 & 8 \\ \mu\left[\mathrm{mm}^{-1}\right] & 0.366 & 3.154 & 0.220 & 0.188 \\ \lambda(\AA) & 0.71073 & 1.54180 & 0.71073 & 0.71073 \\ \text { Refl. measured } & 106322 & 25591 & 71847 & 212055 \\ \text { Refl. unique } / R_{\text {int }} & 10437 / 0.027 & 7555 / 0.045 & 7123 / 0.033 & 16139 / 0.046 \\ \text { Refl. with } I>n \sigma(I) & 8655, \mathrm{n}=3 & 7515, \mathrm{n}=-3 & 5605, \mathrm{n}=3 & 11076, \mathrm{n}=3 \\ \mathrm{Nb} \text { parameters } & 496 & 649 & 354 & 649 \\ \text { Refinement on } & \mathrm{F} & \mathrm{F} & \mathrm{F} & \mathrm{F} \\ R \text { with } I>n \sigma(I) & 0.0499 & 0.0564 & 0.0618 & 0.0503 \\ R_{w} \text { with } I>n \sigma(I) & 0.0593 & 0.1167 & 0.0680 & 0.0623 \\ \text { GooF } & 1.024 & 0.993 & 0.985 & 0.999 \\ \Delta \rho_{\text {max }} / \Delta \rho_{\text {min }}\left[\mathrm{e} . \AA^{-3}\right] & 2.27 /-1.03 & 0.86 /-0.78 & 1.19 /-0.44 & 0.61 /-0.54\end{array}$

\section{Acknowledgments}

Beyond the Ministère de l'Enseignement Supérieur de la Recherche et de la Technologie and the Université Paul Sabatier, the authors thank the Centre National de la Recherche Scientifique (CNRS).

\section{Supporting Information}

The supporting Information of this article can be found under https://...

$-{ }^{1} \mathrm{H},{ }^{13} \mathrm{C}$, and ${ }^{31} \mathrm{P}$ NMR spectra for all new compounds (2-9).

\section{Author Information}

Corresponding author: *E-mail for Y.C.: yves.canac@lcc-toulouse.fr 


\section{ORCID:}

Carine Duhayon: 0000-0001-7345-8782

Noël Lugan: 0000-0002-3744-5252

Yves Canac: 0000-0002-3747-554X

\section{Notes and References}

[1] a) Z. B. Zhu, Y. Wei, M. Shi, Chem. Soc. Rev. 2011, 40, 5534-5563; b) M. Rubin, M. Rubina, V. Gevorgyan, Synthesis 2006, 8, 1221-1245; c) R. Walsh, Chem. Soc. Rev. 2005, 34, 714-732; d) A. Sekiguchi, V. Y. Lee, Chem. Rev. 2003, 103, 1429-1447; e) D. Bourissou, G. Bertrand, Acc. Chem. Res. 1999, 32, 561-570.

[2] a) L. K. Sydnes, Chem. Rev. 2003, 103, 1133-1150; b) M. S. Baird, Chem. Rev. 2003, 103, 12711294.

[3] J. E. Baldwin, Chem. Rev. 2003, 103, 1197-1212.

[4] a) R. Breslow, J. T. Groves, J. Am. Chem. Soc. 1970, 92, 984-987; b) R. Breslow, J. Am. Chem. Soc. 1957, 79, 5318.

[5] a) D. J. M. Lyons, R. D. Crocker, M. Blümel, T. V. Nguyen, Angew. Chem. Int. Ed. 2017, 56, 1466-1484; b) K. Komatsu, T. Kitagawa, Chem. Rev. 2003, 103, 1371-1427; c) Z. I. Yoshida, Pure Appl. Chem. 1982, 54, 1059-1074.

[6] a) J. S. Bandar, T. H. Lambert, Synthesis 2013, 45, 2485-2498; b) Z. I. Yoshida, Y. Tawara, J. Am. Chem. Soc. 1971, 93, 2573.

[7] a) D. Holschumacher, C. G. Hrib, P. G. Jones, M. Tamm, Chem. Com. 2007, 3661-3663; b) V. Lavallo, Y. Canac, B. Donnadieu, W. W. Schoeller, G. Bertrand, Science 2006, 312, 722-724.

[8] a) Y. Canac, Chem. Asian. J. 2018, 13, 1872-1887; b) M. Alcarazo, Acc. Chem. Res. 2016, 49, 1797-1805; c) Y. Canac, C. Maaliki, I. Abdellah, R. Chauvin, New. J. Chem. 2012, 36, 17-27; d) J. Petuskova, H. Bruns, M. Alcarazo, Angew. Chem. Int. Ed. 2011, 50, 3799-3802.

[9] a) A. G. Barrado, J. M. Bayne, T. C. Johnstone, C. W. Lehmann, D. W. Stephan, M. Alcarazo, Dalton. Trans. 2017, 46, 16216-16227; b) R. Weiss, C. Priesner, H. Wolf, Angew. Chem. Int. Ed. 1979, 18, 472-473. 
[10] a) S. Conejero, M. Song, D. Martin, Y. Canac, M. Soleilhavoup, G. Bertand, Chem. Asian. J. 2006, 1-2, 155-160 ; b) S. Conejero, Y. Canac, F. S. Tham, G. Bertrand, Angew. Chem. Int. Ed. 2004, 43, 4089-4093; c) R. Weiss, R. May, B. Pomrehn, Angew. Chem. Int. Ed. 1996, 35, 1232-1234.

[11] J. W. Dube, Y. Zheng, W. Thiel, M. Alcarazo, J. Am. Chem. Soc. 2016, 138, 6869-6877.

[12] CCDC 1942815 [2](OTf) 2 , CCDC 1942816 [7](OTf)2, CCDC 1942817 [8](OTf)2, and CCDC 1942818 [9] Cl contain the supplementary crystallographic data for this paper. These data can be obtained free of charge from the Cambridge Crystallographic Data Centre via www.ccdc.cam.ac.uk/data_request/cif.

[13] R. Chotima, T. Dale, M. Green, T. W. Hey, C. L. McMullin, A. Nunns, A. G. Orpen, I. V. Shishkov, D. F. Wass, R. L. Wingad, Dalton Trans. 2011, 40, 5316-5323.

[14] S. O. Grim, E. F. Davidoff, T. J. Marks, Z. Naturforsch. B: Anorg. Chem. Org. Chem. Biochem. Biophys. Biol. 1971, 26, 184-190.

[15] J. An, R. M. Denton, T. H. Lambert, E. D. Nacsa, Org. Biomol. Chem. 2014, 12, 2993-3003.

[16] A. Padwa, J. M. Kassir, S. L. Xu, J. Org. Chem. 1991, 56, 6971-6972.

[17] A. de Meijere, D. Faber, U. Heinecke, R. Walsh, T. Müller, Y. Apeloig, Eur. J. Org. Chem. 2001, 663-680.

[18] a) H. Kojima, K. Ozaki, N. Matsumura, H. Inoue, J. Chem. Research(S), 1991, 324-325; b) H.

Kojima, K. Ozaki, N. Matsumura, H. Inoue, Bull. Chem. Soc. Jpn. 1991, 64, 2298-2299.

[19] a) Y. Yagyu, N. Matsumura, H. Tanaka, Z. Maeda, H. Inoue, J. Chem. Soc. Perkin Trans 1, 1995,

117-118; b) R. Weiss, K. G. Wagner, C. Priesner, J. Macheleid, J. Am. Chem. Soc. 1985, 107, 44914499.

[20] S. Espenlaub, H. Gerster, G. Maas, Arkivoc 2007, 114-131.

[21] A. Poloukhtine, V. V. Popik, J. Org. Chem. 2003, 68, 7833-7840.

[22] L. Palatinus, G. Chapuis, J. Appl. Cryst. 2007, 40, 786-790.

[23] P. W. Betteridge, J. R. Carruthers, R. I. Cooper, K, Prout, D. J. Watkin, J. Appl. Cryst. 2003, 36, 1487.

[24] P. v.d. Sluis, A. L. Spek, Acta Cryst. 1990, a46, 194-201.

[25] R. H. blessing, Acta Cryst. 1995, a51, 33-38. 


\section{Phosphorus based cyclopropenium cations}
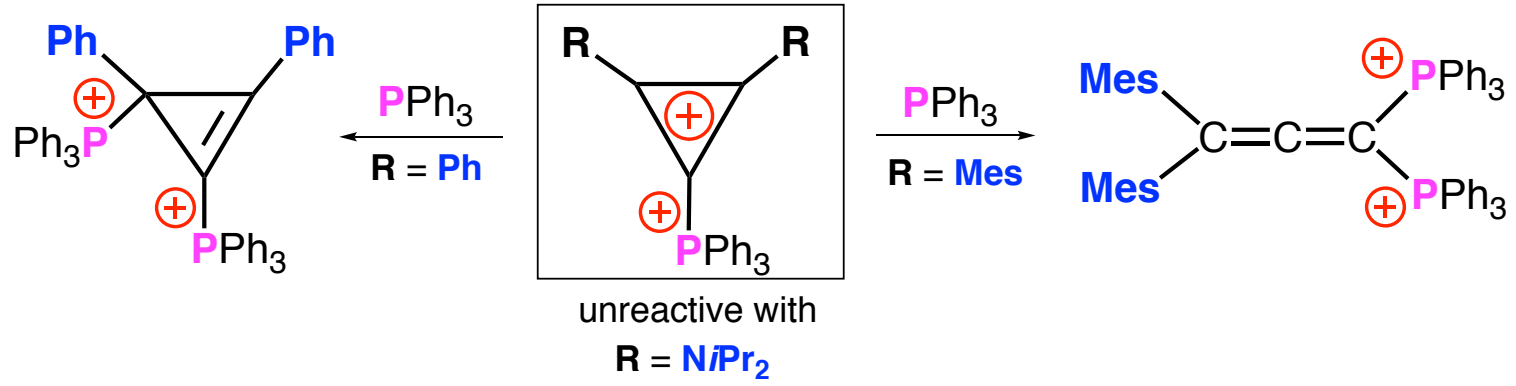

The reactivity of cyclopropenium substituted phosphonium salts towards $\mathrm{PPh}_{3}$ is controlled by the nature of cyclopropenyl substituents, favoring either the cyclopropenic form $(\mathrm{R}=\mathrm{Ph})$ or the linear allenic form $(\mathrm{R}=\mathrm{Mes})$. 